\title{
CASH FLOW, PROFITABILITY, LIQUIDITY AND INVESTMENT IN INDONESIA WITH FINANCIAL CONSTRAINT AS VARIABLE MODERATING
}

Ibnu Damanudin ${ }^{1}$

Risal Rinofah ${ }^{2}$

Economics Faculty of Sarjanawiyata Tamansiswa University, Jl. Kusumanegara No. 121 Yogyakarta

Article Information

Sejarah Artikel:

Diterima : 3 Desember 2019

Disetujui : 4 Desemnber 2019

Dipublikasikan : 3 Maret 2020

Keywords:

Cash flow, profitability, liquidity, investment financial constraint

\begin{abstract}
The purpose of this study is to determine the sensitivity of cash flow, profitability, liquidity, on investments with financial constraints as moderating variables. In manufacture company food and beverage sub-sector company for the period 2015-2018. The population in this study are all food and beverage sub-sector companies listed on the Indonesia Stock Exchange. The observation period used are 2015-2018 or 4 years. The sample is using purposive sampling method, so that a total sample of 10 samples was obtained multiplied by the observation period for 4 years to 40 research data. Data analysis technique used is multiple linear analysis method with a significant level of $5 \%$ (0.05). The results of this study indicate that cash flow and liquidity are not reflected on investments. While the profitability variable has a significant positive effect on investment. Different results are billed when cash flow and liquidity are moderated by financial constraints, cash flow and liquidity have a greater effect on non-financial constrained companies. While profitability does not have a different effect on financial constraint or unconstraint companies
\end{abstract}




\section{PENDAHULUAN}

Pemilihan sumber dana untuk berinvestasi menjadi hal yang harus dipertimbangkan secara serius oleh manager perusahaan, karena setiap sumber dana akan menimbulkan biaya modal tersendiri, oleh karena itu manager memiliki peran yang sangat penting dalam pengambilan kebijakan investasi tersebut. Manager keuangan dalam memilih sumber dana yang berasal dari internal daripda eksternal, karena biaya yang ditimbulkan lebih sedikit dibandingkan sumber yang berasal dari eksternal, Donaldson (1961) dan Hovakian (2001).

Tingkat investasi suatu perusahaan akan sealalu terkait dengan penggunaan sumber modal internal, Salah satunya adalah arus kas. Menurut Hovakimian (2009), pada saat arus kas perusahaan rendah, manajer cenderung menginvestasikan lebih banyak sumber daya daripada yang mereka inginkan. Hal ini menunjukan bahwa arus kas berpengaruh terhadap keputusan investasi perusahaan. Pengaruh arus kas terhadap investasi juga didukung dengan Bukti empiris yang dikemukakan oleh Denis dan Sibilkov (2009), Guariglia (2009), (Hidayat, 2010) (Kerja, Keputusan, Aktiva, \& Zaki, 2013), dan (Rinofah, 2016) (Lerskullawat, 2018) dalam penelitiannya menyatakan bahwa pendanaan internal melalui arus kas memiliki pengaruh positif dan signifikan terhadap keputusan investasi. Namun, hal ini kontradiktif dengan penelitian (Chen \& Chen, 2012) (Senjani, n.d.) yang menunjukan bahwa arus kas tidak berpengaruh terhadap keputusan investasi.

Menurut Kaplan dan Zingales (1997), Likuiditas merupakan kemampuan perusahaan untuk menghasilkan kas dalam memenuhi kebutuhan perusahaan baik jangka panjang maupun jangka pendek. Pengertian tersebut secara eksplisit menunjukkan apakah dengan kas yang tersedia perusahaan mengalami kesulitan untuk mendanai investasinya atau tidak. Perusahaan dikatakan tidak mengalami kesulitan dalam mendanai investasinya apabila perusahaan mampu menghasilkan kas dalam membiayai investasi. Dari pengertian tersebut, Menunjukan bahwa tingkat likuiditas sebuah perusahaan akan berpengaruh terhadap keputusan investasi perusahaan. Hal tersebut sejalan dengan penelitian yang dilakukan oleh (Hidayat, Wahyudi, \& Muharam, 2018) (Graham \& Harvey, 2009) tentang likuiditas dan kaitannya dengan investasi yang menemukan bahwa likuiditas berhubungan positif dengan keputusan investasi. Sebaliknya Lindananty (2004), Prasetyantoko (2007) dalam penelitiannya menunjukkan bahwa likuiditas berhubungan negatif terhadap keputusan investasi.

Financial constraint adalah kondisi dimana sumber dana perusahaan yang berasal dari eksternal memiliki biaya modal yang sangat tinggi hal ini disebabkan karena hutang yang tinggi dan bunga yang harus dikembalikan juga tinggi. Yang akan berpengaruh terhadap laba yang diperoleh oleh perusahaan sehingga perusahaan memiliki pembagian dividen yang rendah (low 
divivdend payout) Fazzari et al. (1988), Perusahaan yang membagikan dividen diklasifikasikan sebagai perusahaan yang tidak mengalami kendala keuangan sedangkan perusahaan yang tidak membagikan dividen adalah perusahaan yang mengalami kendala keuangan. Pengukuran financial constraint menurut Fazzari et al adalah dengan menggunakan ukuran perushaan (firm size), pembayaran dividen (dividend payout), dan peringkat kelas investasi (investment grading rate).

Keputusan investasi dan kendala keuangan dipengaruhi oleh oleh tingkat arus kas dan likuiditas pada sebuah perusahaan. Semakin tinggi kendala keuangan maka penggunaan arus kas dan likuiditas pada sebuah perusahaan juga akan mengalami peningkatan. Bahwa keputusan investasi pada perusahaan yang mengalami kendala keuangan cenderung memiliki tingkat arus kas dan likuiditas yang lebih tinggi daripada perusahaan yang tidak mengalami kendala keuangan Hidayat (2010).

Penelitian yang dilakukan oleh Hidayat (2010) (Hidayat et al., 2018) menunjukkan adanya perbedaan temuan sensitivitas likuiditas dengan keputusan investasi perusahaan ketika dimoderasi oleh financial constraints (hambatan finansial). Hasil penelitian menunjukan bahwa likuiditas lebih sensitif terhadap keputusan investasi pada perusahaan yang mengalamai financial constraint. Hal tersebut berbeda dengan dengan hasil penelitian Prasetyantoko (2007) yang menunjukan bahwa likuiditas lebih sensitif terhadap keputusan investasi perusahaan pada perusahaan NFC (Non Financially Constrained) dibandingkan perusahaan FC (Financially Constrained).

Penelitian tentang sensitivitas arus kas terhadap keputusan invesatsi juga menunjukan perbedaan yang siginifikan ketika arus kas dimoderasi oleh financial constraint, penelitian yang dilakukan oleh Denis dan Sibilkov (2009), Guariglia. A (2009) Hidayat (2010), (Tiwari, Mohnen, Palm, \& Loeff, n.d.) Zaki (2013), menunjukan bahwa arus akan memiliki efek yang lebih kuat atau lebih sensitif pada perusahaan yang mengalami kendala keuangan/financially constrained company. Namun, hal ini kontradiktif dengan penelitian yang dilakukan oleh Prasetyantoko (2006), (Chen \& Chen, 2012) (Rokhmawati, 2019) yang menunjukan bahwa arus kas memiliki hubungan negatif terhadap investasi perusahaan FC (Financially Constrained).

Dari pengantar dan bukti empiris diatas dapat kita lihat bahwa ada inkonsistensi hasil studi diantara studi sebelumnya. Hal ini menarik karena pengujian mengenai penelitian serupa masih jarang dilakukan di Indonesia. Untuk membedakan Penelitian ini dengan penelitian yang lain, penelitian ini akan menambah profitabilitas sebagai variabel independen.

Berdasarkan pengantar tersebut dan bukti empiris pada penelitian sebelumnya, maka penelitian ini bertujuan untuk untuk menguji pengaruh likuiditas, arus kas, dan profitabilitas terhadap keputusan 
investasi yang dimoderasi oleh kendala keuangan (financial constraint). Pengambilan sampel dan populasi untuk penelitian ini adalah dengan melihat perusahaan manufaktur yang tercatat di Bursa Efek Indonesia sub sektor industri makanan dan minuman.

\section{LITERATUR REVIEW DAN HIPOTESIS}

\section{Arus kas berpengaruh terhadap investasi}

Sumber dana yang digunakan oleh perusahaan dalam berinvestasi memiliki biaya modal yang perlu dipertimbangkan, itulah sebabnya perusahaan berkembang yang melakukan investasi besar memilih untuk menggunakan sumber dana dari internal daripada sumber eksternal karena pertimbangan pada biaya modal (Hovakimian dan Titman, 2006). Biaya modal untuk sumber dana eksternal akan lebih mahal daripada sumber dana internal terutama terkait dengan asimetri informasi. Dengan demikian, tingkat investasi suatu perusahaan akan selalu terkait dengan penggunaan sumber modal internal. Arus kas sering dikaitkan dengan investasi yang dilakukan oleh perusahaan, yang bertujuan untuk meningkatkan pertumbuhan keuangan dan kemakmuran pemilik.

Hovakimian (2009), menyatakan bahwa pada saat arus kas perusahaan rendah, manajer cenderung menginvestasikan lebih banyak sumber daya daripada yang mereka inginkan. Pengaruh arus kas terhadap investasi juga didukung dengan Bukti empiris yang dikemukakan oleh Denis dan Sibilkov
(2009), Guariglia (2009), (Hidayat, 2010), Zaki (2013), dan (Rinofah, 2016) dalam penelitiannya menyatakan bahwa pendanaan internal melalui arus kas memiliki pengaruh terhadap keputusan investasi. Namun, hal ini kontradiktif dengan penelitian Chen dan Chen (2011), Senjani (2014) yang menunjukan bahwa arus kas tidak berpengaruh terhadap keputusan investasi. Sesuai dengan pengantar diatas maka hipotesis pertama dalam penelitian ini adalah sebagai berikut:

HI: Arus kas memiliki efek positif terhadap investasi

\section{Profitabilitas terhadap investasi \\ berpengaruh}

Sumber dana internal lain yang dapat mendorong investasi perusahaan adalah profitabilitas perusahaan. Selain menunjukkan keberhasilan perusahaan dalam kinerja di tahun sebelumnya, profitabilitas juga menunjukkan ketersediaan dana untuk kegiatan operasi, termasuk untuk kegiatan investasi. Teori Pecking Order menyatakan bahwa Perusahaan dengan tingkat profitabilitas tinggi menunjukkan tingkat utang yang rendah, karena perusahaan dengan profitabilitas tinggi memiliki sumber dana internal yang melimpah (Breadley, Myers, \& Marcus, 2007). Berdasarkan uraian di atas, hipotesis yang dirumuskan dalam penelitian ini adalah sebagai berikut. Dengan profitabilitas yang tinggi, maka perusahaan akan cenderung memiliki tingkat investasi yang tinngi. Penelitian Rinofah (2016), menunjukan bahwa profitabilitas memiliki efek positif terhdap 
investasi. Berdasarkan uraian di atas, hipotesis yang dirumuskan dalam penelitian ini adalah sebagai berikut:

H2: Profitabilitas memiliki efek positif terhadap investasi

\section{Likuiditas berpengaruh terhadap investasi}

Menurut Kaplan dan Zingales (1997), Likuiditas merupakan kemampuan perusahaan untuk menghasilkan kas dalam memenuhi kebutuhan perusahaan baik jangka panjang maupun jangka pendek. Pengertian tersebut secara eksplisit menunjukkan apakah dengan kas yang tersedia perusahaan mengalami kesulitan untuk mendanai investasinya atau tidak. Perusahaan dikatakan tidak mengalami kesulitan dalam mendanai investasinya apabila perusahaan mampu menghasilkan kas dalam membiayai investasi. Dari pengertian tersebut, Menunjukan bahwa tingkat likuiditas sebuah perusahaan akan berpengaruh terhadap keputusan investasi perusahaan. Hal tersebut sejalan dengan penelitian yang dilakukan oleh Hidayat (2010), Murillo Campello, Erasmo Giambona, John R. Graham, dan Campbell R. Harvey (2010) tentang likuiditas dan kaitannya dengan investasi yang menemukan bahwa likuiditas berhubungan positif dengan keputusan investasi. Sebaliknya Lindananty (2004), Prasetyantoko (2007) dalam penelitiannya menunjukkan bahwa likuiditas berhubungan negatif terhadap keputusan investasi. Berdasarkan uraian di atas, hipotesis yang dirumuskan dalam penelitian ini adalah sebagai berikut

H3: Likuiditas memiliki efek positif terhadap investasi

Financial constraint, arus kas, profitability, Likuiditas dan investasi

Menurut Fazzari et al (1998), financially constrained firm perusahaan yang mempunyai hambatan untuk memperoleh pendanaan eksternal Alasan utama terjadinya financially constrained pada perusahaan adalah karena pendanaan eksternal tidak dapat menjadi pengganti yang sempurna untuk pendanaan internal. Perusahaan yang mengalami kendala keuangan mempunyai tingkat dividend payout ratio yang rendah. Ada dua alasan rendahnya tingkat dividend payout ratio (DPR) bagi perusahaan yang mengalami kendala keuangan. Pertama, perusahaan membutuhkan dana untuk investasi, namun pendanaan untuk investasi tersebut melebihi internal cash flow yang dimiliki perusahaan dan untuk itu perusahaan mempertahankan semua pendanaan internal berbiaya rendah yang mampu perusahaan hasilkan. Kedua, perusahaan hanya mempunyai sedikit atau bahkan tidak mempunyai pemasukan untuk didistribusikan kepada pemegang saham.

Arus kas merupakan faktor penting dalam investasi, Namun, ada faktor-faktor lain yang dapat memengaruhi sensitivitas arus kas, karena arus kas juga memiliki hubungan positif dengan pertumbuhan investasi (Carpenter dan Peterson, 2002). Ketika arus kas memiliki sensitivitas tinggi, hal itu 
dapat mempengaruhi pertumbuhan investasi dan membawanya ke pertumbuhan negatif. Ketika sebuah perusahaan tidak bisa lagi mengandalkan arus kas mereka, maka mereka harus mencari sumber dana lain untuk menggantikan arus kas yang banyak digunakan. Penelitian tentang sensitivitas arus kas terhadap keputusan invesatsi juga menunjukan perbedaan yang siginifikan ketika arus kas dimoderasi oleh financial constraint, penelitian yang dilakukan oleh Denis dan Sibilkov (2009), Guariglia. A (2009) Hidayat (2010), Zaki (2013), menunjukan bahwa arus akan memiliki efek yang lebih kuat atau lebih sensitif pada perusahaan yang mengalami kendala keuangan/financially constrained company. Namun, hal ini kontradiktif dengan penelitian yang dilakukan oleh Prasetyantoko (2006), Chen and Chen (2011), Husain (2014) yang menunjukan bahwa arus kas memiliki hubungan negatif terhadap investasi pada perusahaan FC (Financially Constrained).

Almeida et al. (2004) menyatakan bahwa peningkatan profitabilitas dapat menjadi salah satu alternatif sumber dana ketika arus kas sangat rendah. Sejalan dengan Ferreira dan Vilela (2004), Almeida et al. (2004) menjelaskan bahwa perusahaan yang mengalami kendala keuangan akan cenderung melakukan kebijakan kas secara optimal untuk menyeimbangkan profitabilitas investasi saat ini dan masa depan. Dengan demikian, mereka mengantisipasi kendala pembiayaan di masa depan dengan menyimpan uang tunai dari laba saat ini, yang berarti bahwa perusahaan yang mengalami kendala keuangan akan meningkatkan kepemilikan kas mereka untuk keberlanjutan masa depan mereka.

Kebijakan tunai di perusahaan yang mengalami kendala keuangan selalu merupakan kebalikan dari perusahaan yang tidak memiliki kendala finansial. Perusahaan yang tidak memiliki kendala finansial cenderung dapat mendanai investasi mereka yang memiliki NPV positif (Net Present Value). Ketika perusahaan mengalami sensitivitas arus kas untuk berinvestasi, mereka cenderung menggunakan aset sebagai jaminan dalam berinvestasi. Perusahaan yang tidak memiliki kendala finansial cenderung memaksimalkan kas yang tersedia untuk melakukan investasi dengan proyek yang memiliki NPV positif. Keuntungan yang tinggi menunjukkan pertumbuhan yang baik unuk masa depan perusahaan. Hubungan antara profitabilitas dan investasi telah diuji oleh AlNajjar dan Belkaoui (2001), (Rinofah, 2016) yang menemukan hasil positif dan signifikan.

Likuiditas merupakan kemampuan perusahaan untuk memenuhi kewajibannya terutama kewajiban jangka pendek (Hanafi dan Halim, 2005). Menurut Riyanto (1997) perusahaan yang likuid adalah perusahaan yang memiliki kekuatan sedemikian besarnya sehingga mampu memenuhi segala kewajiban finansialnya yang segera harus dipenuhi, kemampuan membayar ini berhubungan dengan penyelenggaraan proses produksi. Perusahaan yang mengalami kendala keuangan cenderung menggunakan 
likuiditas untuk mendanai investasi. Hal ini karena perusahaan yang mengalami kendala keuangan memiliki keterbatasan akses terhadap pasar modal dan pinjaman eksternal, yang menunjukkan keterbatasan finansial. Sehingga akan sulit bagi perusahaan mengambil kesempatan investasi yang menguntungkan untuk investasi. Dengan kata lain bahwa perusahaan yang mengalami kendala keuangan mempunyai nilai perusahaan yang rendah.

Penelitian Hidayat (2010) menunjukkan adanya perbedaan temuan sensitivitas likuiditas dengan keputusan investasi perusahaan ketika dimoderasi oleh financial constraints (hambatan finansial). Hasil penelitian menunjukan bahwa likuiditas lebih sensitif terhadap keputusan investasi pada perusahaan yang mengalamai financial constraint. Hal tersebut berbeda dengan dengan hasil penelitian Prasetyantoko (2007) yang menunjukan bahwa likuiditas lebih sensitif terhadap keputusan investasi perusahaan pada perusahaan NFC (Non Financially Constrained) dibandingkan perusahaan FC (Financially Constrained).

Berdasarkan uraian di atas, hipotesis yang dirumuskan dalam penelitian ini adalah sebagai berikut.

H4: Arus kas memiliki efek yang lebih kuat terhadap investasi pada perusahaan yang mengalami kendala keuangan

H5: Profitabilitas memiliki efek yang lebih kuat terhadap investasi pada perusahaan yang mengalami kendala keuangan
H6: Likuiditas memiliki efek yang lebih kuat terhadap investasi pada perusahaan yang mengalami kendala keuangan

\section{METODE PENELITIAN}

Populasi dalam penelitian ini adalah perusahaan manufaktur yang tercatat di bursa efek Indonesia sub sector makanan dan minumna pada tahun 2015-2018. Penelitian ini mengambil sampel dengan metode purposive sampling dan diperoleh sebanyak 10 perusahaan.

\section{Variabel}

\section{Investment}

Investasi dihitung dengan menggunakan rumus (Kaaro, 2004) dalam penelitian (Rinofah, 2016).

$I N V=\frac{\text { cashflow }}{\text { Net fixed Assets }} \times 100 \%=\%$

\section{Cash Flow}

Rumus untuk Menghitung arus kas (Hovakimian, 2009)

$$
C F=\frac{\text { NOPAT }+ \text { Depreciation }}{\text { Total assets }}=R p
$$

Keterangan:

$\mathrm{CF}$
flow

NOPAT = Net Operating Profit After Tax

Depreciation $=$ Depreciation of fixed assets

Total Assets = Total number of assets owned by the company

\section{Profitability}

Rumus yang digunakan untuk mengukur profitabilitas (Shelly dan Munzir, 2015) 


$$
R O A=\frac{E A T}{\text { Total Aset }} \times 100 \%=\%
$$

\section{Liquidity}

Likuiditas dihitung menggunakan rumus (Shelly dan Munzir, 2015).

$$
\begin{gathered}
\text { liquidiy }=\frac{\text { current assets }}{\text { current liabilities }} \times 100 \% \\
=\%
\end{gathered}
$$

\section{Financial Constraint}

Untuk mengukur Financial Constraint adalah dengan mengklasifikasikan perusahaan dengan pembagian dividen.

a. Jika perusahaan membagikan dividen maka perusahaan tersebut tidak mengalami kendala keuangan / Non Financially Constrained (NFC). Perusahaan yang tidak mengalami kendala keuangan diberi skor 1 .

b. Jika perusahaan tidak membagikan dividen maka perusahaan tersebut mengalami kendala keuangan Financially Constrained Company (FC). Perusahaan yang mengalami kendala keuangan diberi skor 0 .

\section{Model Dan Metode Uji Hipotesis}

sebagai berikut:

Persamaan dapat dituliskan

$$
\text { Investment }=\alpha 0+\beta 1 C F+
$$

$\beta 2 R O A+\beta 3 L I Q+\beta 4 F C * C F+$

$\beta 5 F C * R O A+\beta 6 F C * L I Q+\varepsilon$

Keterangan:

$F C=$ Dummy Financial Constraint

$(1=$ Financially Constraint, $0=$

Financially Unconstraint)

CF $=$ Cash Flow

ROA = Return on Asset

$L I Q \quad=$ Liquidity

$F C * C F=$ interaction between Dummy

Financial Constraint with Cash Flow

$F C * R O A=$ interaction between Dummy

Financial Constraint with Return on

Asset

$F C * L I Q=$ interaction between Dummy

Financial Constraint with Liquidity

Pengujian pada hipotesis 1 membuktikan $\beta 1$ positif dan signifikan, bersama dengan pengujian pada hipotesis 2 yang menunjukkan $\beta 2$ positif dan signifikan. Demikian pula, tes pada hipotesis 3 dan 4 membuktikan bahwa $\beta 4$ dan $\beta 5$ memiliki tanda positif dan signifikan

\section{HASIL DAN PEMBAHSAN}

\begin{tabular}{|c|c|c|c|}
\hline \multirow[t]{2}{*}{ Category } & \multicolumn{3}{|c|}{ Financially Constrained } \\
\hline & Min & Max & Mean \\
\hline Invest & 0.02 & 1.16 & 0.25 \\
\hline $\mathrm{CF}$ & 0.02 & 0.32 & 0.19 \\
\hline ROA & -5.67 & 28.12 & 4.88 \\
\hline$\overline{C R}$ & 73.35 & 339.93 & 172.13 \\
\hline $\begin{array}{l}\text { Pei } \\
\text { nengalam } \\
\text { nemiliki } \\
\text { ebih tingg } \\
\text { nengalam }\end{array}$ & $\begin{array}{l}\text { ahaan } \\
\text { kend } \\
\text { ai rata-r } \\
\text { laripada }\end{array}$ & \begin{tabular}{l}
\multicolumn{2}{c}{ yang } \\
la ke \\
perusaha
\end{tabular} & $\begin{array}{r}\text { tidak } \\
\text { dangan } \\
(0,34) \\
\text { n yang } \\
\text { Sama }\end{array}$ \\
\hline
\end{tabular}

Descriptive Statistic

\begin{tabular}{lrrr}
\hline Category & \multicolumn{3}{c}{ Non Financially } \\
& \multicolumn{3}{c}{ Constrained } \\
& Min & Max & Mean \\
Invest & 0.06 & 1.16 & 0.34 \\
CF & 0.17 & 1.05 & 0.38 \\
ROA & 3.73 & 52.67 & 16.64 \\
CR & 58.42 & 507.28 & 224.77 \\
\hline
\end{tabular}


halnya dengan ketersediaan arus kas, profitabilitas dan likuiditas, perusahaan yang tidak mengalami kendala keuangan cenderung memiliki skor yang lebih tinggi daripada perusahaan yang mengalami kendala keuangan.

\section{HYPOTESYS TESTING AND DISCUSSION}

\begin{tabular}{lcc}
\hline & Coefficients $^{\boldsymbol{a}}$ \\
\hline Model & $\mathbf{B}$ & Sig. \\
(Constant) & -2.332 & .001 \\
CF & -.082 & .789 \\
ROA & .768 & .002 \\
CR & .470 & .100 \\
FC & 1.797 & .020 \\
CF*FC & -1.378 & .022 \\
ROA*FC & .234 & .154 \\
CR*FC & -.598 & .008 \\
\hline
\end{tabular}

\section{Pengaruh Arus kas Terhadap Investasi}

Hipotesis pertama dalam penelitian ini adalah arus kas berpengaruh positif terhadap investasi, hipotesis ini mengasumsikan bahwa dengan ketersediaan arus kas yang tinggi maka perusahaan akan cenderung memanfaatkan arus kas yang tersedia untuk berinvestasi.

Berdasarkan hasil analisis data diketahui bahwa Arus Kas memiliki nilai signifikan uji $\mathrm{t}$ sebesar $0,789>0,05$, dan nilai beta $-0,082$ artinya Arus Kas tidak berpengaruh terhadap Investasi pada perusahaan manufaktur sub sektor makanan dan minuman yang terdaftar di Bursa Efek
Indonesia periode 2015-2018, dengan demikian hipotesis pertama yang menyatakan bahwa arus kas berpengaruh positif terhadap keputusan investasi pada perusahaan Manufaktur sub sektor makanan dan minuman tidak dapat diterima atau ditolak.

Hasil pengujian hipotesis pertama menunjukkan hal yang berbeda dengan hipotesis yang telah dibangun. Hal ini tidak mengkonfirmasi hasil penelitian yang telah dilakukan oleh Fitria (2010), (Kerja et al., 2013) Rinofah (2016), (Lerskullawat, 2018), Rokhmawati (2019) yang telah mendokumentasikan pengaruh positif aliran kas terhadap keputusan invetasi perusahaan.

Hasil uji hipotesis yang
menunjukan arus kas tidak
berpengaruh terhadap investasi terjadi
apabila perusahaan lebih memilih mengalokasikan arus kas untuk aktivitas pendanaan dan aktivitas operasi dibandingkan mengalokasikan dana yang tersedia untuk aktivitas investasi. Penelitian yang menunjukan arus kas tidak berpengaruh terhadap arus kas juga dikemukakan oleh (Senjani, n.d.)senjani (2014), yang menyatakan arus kas tidak berpengaruh terhadap keputusan investasi dikarenakan kebijakan setiap perusahaan berbedabeda dalam pengambilan keputusan untuk berinvestasi. Hal lain yang dapat mempengaruhi adalah kebijakan pengalokasian pos-pos lain untuk mebayar utang ataupun dividen kepada para pemegang saham.

Pengaruh Profitabilitas terhadap Investasi 
Berdasarkan hasil analisis data diketahui bahwa Profitabilitas memiliki nilai signifikan uji t sebesar $0,002<0,05$, dan nilai beta 0,768 artinya Profitabilitas berpengaruh secara positif dan signifikan terhadap Investasi pada perusahaan manufaktur sub sektor food and beverages yang terdaftar di Bursa Efek Indonesia periode 2015-2018. Hal ini sejalan dengan penelitian yang dilakukan oleh dan rinofah (2016).

Uji hipotesis kedua yang menunjukan arus kas berpengaruh terhadap investasi mengkonfirmasi bahwa profitabilitas selain menunjukan keberhasilan kinerja perusahaan juga menunjukan ketersediaan dana untuk kegiatan operasi dan investasi. Hipotesis kedua dapat disimpulkan bahwa dengan ketersediaan laba yang tinggi maka perusahaan akan cenderung memanfaatkan dana mereka untuk berinvestasi di perusahaan.

\section{Pengaruh Likuiditas Terhadap Investasi}

Berdasarkan hasil analisis data diketahui bahwa Likuiditas memiliki nilai signifikan uji t sebesar $0,100>0,05$, artinya Likuiditas tidak berpengaruh terhadap Investasi pada perusahaan manufaktur sub sektor food and beverages yang terdaftar di Bursa Efek Indonesia periode 20152018.

Hasil pengujian hipotesis ketiga menunjukkan hal yang berbeda dengan hipotesis yang telah dibangun. Hal ini tidak mengkonfirmasi hasil penelitian yang telah dilakukan oleh Hidayat (2010), (Hidayat et al., 2018)yang telah mendokumentasikan pengaruh positif aliran kas terhadap keputusan invetasi perusahaan

Uji hipotesis ketiga yang menunjukan bahwa likuiditas tidak berpengaruh terhadap investasi hal ini karena current ratio atau ketersediaan likuiditas yang ada pada perusahaan lebih berfokus untuk pemenuhan kewajian jangka pendek perusahaan dibandingkan pengalokasian dana untuk investasi. Likuiditas yang tidak berpengaruh terhadap investasi sejalan dengan penelitain lerskullawat (2018).

hal ini dapat terjadi apabila perusahaan lebih menggunakan modal kerja mereka untuk melakukan kegiatan operasional dan berjaga-jaga apabila terjadi kebangkrutan, dibandingkan menggunakan modal kerja yang ada untuk kegiatan investasi.

\section{Pengaruh Arus Kas Yang Dimoderasi Oleh Financial Constraint Terhadap Investasi}

Berdasarkan hasil analisis data diketahui bahwa Arus Kas yang dimoderasi oleh Financial Constraint memiliki nilai signifikan uji t sebesar $0,022<0,05$ dan nilai beta $-1,378$, artinya arus kas yang dimoderasi oleh financial constraint berpengaruh negatif terhadap Investasi pada perusahaan manufaktur sub sektor food and beverages yang terdaftar di Bursa Efek Indonesia periode 20152018. Hasil analaisis arus kas yang dimoderasi oleh financial constraint menunjukan pengaruh negative terhadap investasi hal ini sejalan dengan penelitian Kaplan dan Zingales (1997), Chen dan Chen (2011), Husain (2014) rokhmawati (2019) bahwa 


\begin{abstract}
Uji hipotesis kelima menunjukan arus kas yang dimoderasi oleh financial constraint berpengaruh negative terhadap investasi hal ini berarti bahwa pengarus arus kas akan lebih seinsitif pada perusahaan yang tidak mengalami kendala keuangan/ non financialy constrained company. Karena mereka memiliki akses yang mudah dalam hal pendanaan dari eksternal. Hanya perusahaan yang memiliki arus kas besar yang dapat membiayai investasi mereka karena mereka memiliki akses mudah ke pendanaan eksternal. Hasil estimasi kami menunjukkan bahwa perusahaan dengan tingkat arus kas yang tinggi akan memiliki tingkat investasi yang tinggi

\section{Pengaruh Profitabilitas Yang Dimoderasi Oleh Financial Terhadap Investasi}

Berdasarkan hasil analisis data diketahui bahwa Profitabilitas yang dimoderasi oleh financial constraint memiliki nilai signifikan uji $t$ sebesar 0,154 >0,05, artinya Profitabilitas yang dimoderasi oleh financial constraint tidak berpengaruh terhadap Investasi pada perusahaan manufaktur sub sektor food and beverages yang terdaftar di Bursa Efek Indonesia periode 2015-2018.

Hal ini dikarenakan Perusahaan yang secara keuangan mengalami kendala keuangan lebih memilih untuk untuk memangkas kegiatan mereka dalam hal investasi, teknologi, dan pemasaran pada saat mengalami kendala keuangan. Campello, graham dan Harvey (2009). Selain itu, perusahaan yang mengalami financial constraint memiliki laba yang kecil untuk aktivitas investasi, maka dari itu perusahaan akan cenderung menyimpan dana mereka sebagai laba ditahan atau untuk kegiatan operasi dibandingkan dengan kegiatan investasi. Perusahaan yang mengalami kendala keuangan juga cenderung membatalkan proyek besar mereka dan menghambat perusahaan berinvestasi pada proyek-proyek berharga.

\section{Pengaruh Likuiditas Yang Dimoderasi Oleh Financial Constraint Terhadap Investasi}

Berdasarkan hasil analisis data diketahui bahwa Likuiditas yang dimoderasi oleh financial constraint memiliki nilai signifikan uji t sebesar $0,008<0,05$, dan nilai beta $-0,598$ artinya Likuiditas yang dimoderasi oleh financial constraint berpengaruh negatif terhadap Investasi pada perusahaan manufaktur sub sektor food and beverages yang terdaftar di Bursa Efek Indonesia periode 20152018.

Likuiditas yang dimoderasi oleh financial constraint berpengaruh negative terhadap investasi, hal ini berarti bahwa likuiditas memiliki sensitivitas yang lebih tinggi pada perusahaan yang tidak mengalami kendala keuangan non financially constrained company, hal ini dikarenakan NFC memiliki akes yang mudah dalam hal pendanaan dari luar.

Perusahaan tanpa kendala/ NFC dalam hal aset riil yang lebih tinggi dan tingkat arus kas yang lebih tinggi menunjukkan sensitivitas likuiditas yang lebih tinggi dibandingkan dengan perusahaan yang memiliki tingkat aset riil yang 
relatif rendah dan arus kas yang rendah. Dengan demikian dalam temuan kami, perusahaan dengan posisi keuangan yang lebih kuat menunjukkan sensitivitas likuiditas Investasi yang lebih besar daripada perusahaan dengan posisi keuangan yang lebih lemah.

\section{Kesimpulan}

Cash flow dan liquiditas tidak berpengaruh terhadap investasi. Sedangkan variabel profitabilits berpengaruh signifikan positif terhadap investasi. Hasil berbeda ditunjukan pada saat arus kas dan liquiditas di moderasi oleh financial constraint, arus kas dan liquiditas memiliki efek yang lebih kuat pada perusahaan yang tidak mengalami kendala keuangan/ non financialy constrained company. Sedangkan profitabilitas tidak memiliki efek yang berbeda pada perusahaan yang mengalami kedala keuangan dan perusahaan yang tidak mengalami kendala keuangan.

\section{REFERENCES}

AlNajjar and Ahmed Riahi Belkaoui. 2001. "Empirical Validation of a General Model of Growth Opportunities". Journal of Managerial Finance. Vol. 27, No.3, pp. $72-99$.

ALMEIDA, H., MURILlO, C., \& MICHAEL S., W. (2004). The cash flow sensitivity of cash holdings. Advances in Environmental Biology, 7(14), 4795-4801.

Carpenter, R. E., \& Petersen, B. C. (2002). Is the growth of small firms constrained by internal finance? Review of Economics and Statistics, 84(2), 298-309. https://doi.org/10.1162/00346530231 7411541

Chen, H., \& Chen, S. (2012). Investment-cash flow sensitivity cannot be a good measure of financial constraints: Evidence from the time series. Journal of Financial Economics, 103(2), 393-410. https://doi.org/10.1016/j.jfineco.2011 .08 .009

Denis, D. J., \& Sibilkov, V. (2010). Financial constraints, investment, and the value of cash holdings. Review of Financial Studies, 23(1), 247-269. https://doi.org/10.1093/rfs/hhp031

Fazzari, S.M., Hubbard, R.G., Peterson, B.C. 1988. Financing Constraints and Corporate Investment, Brookings Paper on Economic Activity.

Ferreira, M. A., \& Vilela, A. S. (2004). Why do firms hold cash? Evidence from EMU countries. European Financial Management, 10(2), 295-319. https://doi.org/10.1111/j.13547798.2004.00251.x

Fitria, Wenny. 2009. Arus Kas, Kendala Pendanaan, Mispricing, Dan Investasi: Study Empiris Pada Bursa Efek Indonesia. Program Magister Sains dan Doktor Universitas Gadjah Mada Yogyakarta (Unpublished Thesis).

Graham, J., \& Harvey, C. R. (2009). THE REAL EFFECTS OF FINANCIAL CONSTRAINTS :

Guariglia, Alessandra., (2008). Internal Financial constraints. External Financial constraints and investment choice: Evidence from a panel of UK firms. Journal of 
Banking and Finance, 32 , 1795 1809

Hidayat, R. (2010). Keputusan Investasi Dan Financial Constraints: Studi Empiris Pada Bursa Efek Indonesia. Buletin Ekonomi Moneter Dan Perbankan, 12(4), 457-479. https://doi.org/10.21098/bemp.v12i4. 249

Hidayat, R., Wahyudi, S., \& Muharam, H. (2018). Sensitivity of Liquidity, Investment Decision, and Financial Constraints. 10, 37-48.

Hovakimian, A., Hovakimian, G., 2009. Cash Flow Sensitivity of Investment. European Financial Management 15, 47-65.

Hovakimian, Armen, Tim Opler, and Sheridan Titman. 2001. The DebtEquity Choice, The Journal of Financial and Quantitative Analysis.

Hovakimian, $\mathrm{G}$ and Titman Sheridan 2006. Corporate Investment with Financial Constraints: Sensitivity of Investment to Funds from Voluntary Asset Sale, Journal of Money, Credit and Banking, vol. 38, no. 2, pp. 35774

Kaaro, Hermeindito. 2004, Informasi Asimetri dan Kontrol Manajemen: Analisis Kepekaan Investasi dan Leverage Terhadap Pemilihan Sumber-Sumber Pendanaan, Desertasi Program Pascasarjana Universitas Gadjah Mada (Unpublished).

Kaplan, S. N., \& Zingales, L. (2013). Do Financing constraints explain why investment is correlated with cash flow. In Journal of Chemical Information and Modeling (Vol. 53).
https://doi.org/10.1017/CBO9781107 415324.004

Kerja, M., Keputusan, T., Aktiva, I., \& Zaki, M. (2013). Mohamad Zaki; Pengaruh Arus Kas ... 1.

Lerskullawat, A. (2018). Financial development, financial constraint, and firm investment: Evidence from Thailand. Kasetsart Journal of Social Sciences.

https://doi.org/10.1016/j.kjss.2018.01 .010

Prasetyantoko, A. (2007). Financing Constraint and Firm Investment Following a Agustinus Prasetyantoko To cite this version : HAL Id: halshs00133964 Financing Constraint and Firm Investment.

Rinofah, R. (2016). Cash Flow, Profitability, Financial Constraint, and Investment in Indonesia. Sebelas Maret Business Review, 1(1), 0-9. https://doi.org/10.20961/smbr.v1i1.1 320

Rokhmawati, A. (2019). The Effect of Firm Cash Flow on Investment Decision Moderated by Financial Constraint and Mispricing. Indonesian Journal of Economics, Social, and Humanities, 1(2), 77-90. https://doi.org/10.31258/ijesh.1.2.7790

Senjani, Y. P. (n.d.). Analisis FaktorFaktor yang Mempengaruhi Keputusan Investasi pada Perusahaan BUMN. (April 2011).

Tiwari, A., Mohnen, P., Palm, F., \& Loeff, S. Van Der. (n.d.). Financial Constraints, Capital Structure and Innovation: An Empirical Investigation. Isid.Ac.In, 1-74. Retrieved from 
http://www.isid.ac.in/ pu/seminar/09

_04_2010_Paper.pdf 